\title{
DIDELIO MEISTRIŠKUMO LENGVAATLEČIŲ TRENIRUOTĖS VYKSMO KONTROLE் RENGIANTIS ŽIEMOS SEZONO VARŽYBOMS
}

\author{
Eugenijus Trinkūnas, Jonas Poderys, Jūratė Kudirkaitė, Birutė Miseckaitė, Eurelija Venskaitytė \\ Lietuvos kūno kultūros akademija, Kaunas, Lietuva
}

Eugenijus Trinkūnas. Biomedicinos mokslų daktaras. Lietuvos kūno kultūros akademijos Lengvosios atletikos katedros docentas, Kineziologijos laboratorijos mokslo darbuotojas. Mokslinių tyrimų kryptis — organizmo greitosios ir ilgalaikès adaptacijos ypatybės.

\begin{abstract}
SANTRAUKA
Tyrimo tikslas - ¿vertinti lengvaatlečiu CNS (centrinès nervu sistemos) darbingumo ir funkcinès būklès rodikliu bei specialiojo parengtumo kontroliniu pratimu rezultatu kaita rengiantis žiemos sezono varžyboms. Tirta 12 didelio meistriškumo lengvaatlečiu — sprinteriu ir šuolininku (Lietuvos rinktinès nariu ir kandidatu), kurie buvo prisitaike atlikti greitumo jẻgos fizinius krūvius. Per rudens ir žiemos pratybu cikla, pasibaigus ìvairaus kryptingumo mezociklams bei žiemos varžybu laikotarpiu, buvo atliekami visu tiriamuju CNS darbingumo bei funkcinès büklès tyrimai ir paskirti specialiojo parengtumo kontroliniai pratimai. CNS büklei jvertinti buvo taikytas tepingo testas, modifikuotas pagal Ukrainos kūno kultūros universiteto mokslininku parengta CNS funkcinès būkles ir darbingumo rodikliu (CNS paslankumo, pastovumo, bendrojo darbingumo, anaerobinio darbingumo ir anaerobinio darbingumo talpos) vertinimo metodika. Lengvaatlečiu specialiajam parengtumui vertinti parinkome iprastinius rekomenduojamus kontrolinius pratimus: 60 m bégima, šuolị $\dot{k}$ toli ir trišuolị iš vietos bei šuoli $i$ aukšti iš vietos.

Tyrimo rezultatai parodè, kad rengiantis žiemos sezono varžyboms tirtu lengvaatlečiu CNS funkcinès būklès rodikliai gerèjo, tačiau prieš atsakingiausias žiemos sezono varžybas reikšmingai pagerèjo CNS funkcinio paslankumo ir funkcinio pastovumo rodikliai. CNS bendrojo darbingumo, anaerobinio darbingumo ir anaerobinio darbingumo talpos rodikliai prieš pagrindines varžybas reikšmingai sumažejo. Šiu rodikliu reikšmiu sumažejimas gali būti susijęs su priešvaržybiniu psichologiniu stresu. Lvertinus tirtu lengvaatlečiu specialuji parengtumq nustatyta: treniruotės vyksme taikomi kontroliniai pratimai puikiai rodo atletu parengtumo kaita. Visais rengimo etapais rezultatai gerejjo, o geriausiu rodikliu buvo pasiekta prieš atsakingiausias žiemos sezono varžybas, t. y. Lietuvos lengvosios atletikos žiemos čempionata. Varžybinès veiklos rezultatu analize parodè, kad net šeši sportininkai svarbiausiose varžybose pasiekè geriausia žiemos sezono ir net asmenini rezultata. Apibendrindami tyrimo rezultatus pažymime, kad ne visi CNS darbingumo ir funkcinès būkles rodikliai vienodai kinta pratybu metu, o ypač prieš atsakingiausias varžybas — vieniems smarkiai gerëjant, kiti, atvirkščiai, reikšmingai sumažèja. Vis dèlto vertinant sportinès formos kitima galima teigti, kad mūsų tirti sportininkai prieš pagrindines žiemos sezono varžybas buvo igiję optimalia sportinę forma.
\end{abstract}

Raktažodžiai: funkcinè būkle, specialusis parengtumas, sportinè forma.

\section{IVADAS}

$\mathrm{P}$ lanuojant treniruotès vyksmą, treneriui būtina informacija apie sportininko treniruotumo būseną (Jasiūnas, 1982; Raslanas, Skernevičius, 1998; Karoblis, 1999; Poderys ir kt., 2002; Платонов, 2004). Tokia informacija gaunama atliekant specifinius testus, kontrolinius pratimus, funkcinius ir biocheminius tyrimus (Maud, Foster, 1995; Karoblis, 1999; Poderys ir kt., 2002). Testais ivvertiname fizinio išsivysty- mo duomenis, fizinio pajègumo, atskirų fizinių ypatybių lygi, fiziologinių funkcijų gebėjimus, biocheminių tyrimų duomenis, psichomotorinę veiklą. Tai parodo bendraji treniruotumą, fizinị darbingumą (Raslanas, Skernevičius, 1998; Šiupšinskas, 2004). Treneris nuolatos turi lyginti sportininkų varžybų ir kontrolinių pratimų rezultatus, testų ir atlikto krūvio duomenis (Jasiūnas, 1982; Karoblis, 1994, 1999; Платонов, 1997, 
2004). Gauti testų ir kontrolinių pratimų, krūvių dydžių, varžybų duomenys leidžia palyginti ivvairaus meistriškumo sportininku sportinio rengimo vyksma, padeda išsiaiškinti pranašumus ir trūkumus, individualizuoti rengimo priemones ir metodus (Raslanas, Skernevičius 1998; Karoblis, 1999).

Sportuojančiujų darbingumui ir funkcinei būklei îvertinti taikomi fizinio krūvio mèginiai (Edgerton et al., 1986; Bosco, 1999). Anaerobinio darbingumo pokyčiams vertinti tinkamiausi yra judejjimo rezultatyvumą vertinantys testai, nes tiksliau nei bet kuris atskiras pratimas biocheminis anaerobinio darbingumo rodiklis parodo įvykusiu pokyčių laipsni (Bangsbo, 1998). Visgi maksimalaus intensyvumo fizinio krūvio testai nèra tinkami sportininko būklei vertinti, ypač tada, kai lieka nedaug laiko iki atsakingu varžybų. Tokiu atveju testavimas atliekant maksimalaus intensyvumo fizinị krūvị yra papildomas, nepageidaujamas energijos eikvojimas ir papildomas organizmo varginimas.

Šio tyrimo tikslas - nustatyti lengvaatlečiu CNS darbingumo bei funkcinès būklès rodiklių ir specialiojo parengtumo kontrolinių pratimų rezultatų kaitą rengiantis žiemos sezono varžyboms.

\section{METODIKA}

Buvo tiriama 12 didelio meistriškumo lengvaatlečiu (sprinterių ir šuolininku). Visi jie Lietuvos rinktinès nariai ar kandidatai. Tiriamuju amžius - 23,1 1,4 m., ūgis - 178,8 2,0 cm, svoris - 71,4 3,1 kg. Per rudens ir žiemos pratybų cikla, t. y. pasibaigus ivvairaus kryptingumo treniruotės mezociklams bei žiemos varžybų laikotarpiu, buvo įvertintas tiriamuju specialusis parengtumas. Jie turejo atlikti kontrolinius pratimus, o laboratorijoje buvo atliekami CNS darbingumo ir funkcinès būklès tyrimai. Iš viso atlikti penki tyrimai.
Lengvaatlečiu specialiajam parengtumui vertinti parinkti tokie kontroliniai pratimai: $60 \mathrm{~m}$ bègimas, šuoliai į tolị ir trišuolis iš vietos, šuolis $\mathfrak{i}$ aukšti iš vietos. CNS būklei įvertinti taikytas tepingo testas, kurio rezultatai buvo vertinami pagal Ukrainos kūno kultūros universiteto mokslininku parengtą CNS funkcinès būklès ir darbingumo rodikliu (CNS paslankumo, pastovumo, bendrojo darbingumo, anaerobinio darbingumo ir anaerobinio darbingumo talpos) vertinimo metodiką (Зеленцов, Лобановский, 1998).

Taip pat buvo atlikta tirtų sportininkų, dalyvavusių varžybose, pasiektų rezultatų analizè.

Tyrimo metu vertinti individualūs sportininkuc rezultatai, jų vidurkiai $(\overline{\mathrm{X}})$ ir aritmetinio vidurkio paklaidos $(\mathrm{S} \overline{\mathrm{X}})$. Statistinis skirtumo patikimumas buvo vertinamas taikant Stjudento $t$ kriterijų. Skaičiavimai atlikti naudojantis statistiniu „Microsoft Excel“ paketu ir specializuota programa „Statistika“.

\section{TYRIMO REZULTATAI}

Rezultatai parodè, kad tirtų lengvaatlečiǔ, kryptingai besirengiančiu žiemos sezono varžyboms, CNS funkcinès būklès rodikliai gerèjo (1 lent.). Prieš atsakingiausias žiemos sezono varžybas (Lietuvos čempionatą) ypač pagerejjo CNS funkcinio paslankumo (nuo 76,83 \pm 2,70 iki 83,32 \pm 1,97\%) ir funkcinio pastovumo rodikliai (nuo 68,89 $\pm 1,58$ iki 75,20 $\pm 2,99 \%)$. Abiejų CNS rodiklių reikšmių pokytis buvo statistiškai reikšmingas $(\mathrm{p}<0,05)$. CNS bendrojo darbingumo, anaerobinio darbingumo ir anaerobinio darbingumo talpos rodikliai taip pat gerejo, tačiau tik iki ketvirto tyrimo (atitinkamai nuo 56,30 $\pm 1,56$ iki 59,83 $\pm 1,53 \%$, nuo $67,41 \pm 1,91$ iki $71,86 \pm 2,47 \%$ ir nuo $58,31 \pm 1,67$ iki $61,86 \pm 1,61 \%$ ), ir šis reikšmių skirtumas buvo statistiškai patikimas $(\mathrm{p}<0,05)$. Tačiau visi trys CNS rodikliai reikšmingai sumažèjo, palyginus jų vidutines reikšmes su pradinėmis, prieš pagrin-

\begin{tabular}{|c|c|c|c|c|c|c|}
\hline \multirow[b]{2}{*}{ CNS rodiklis } & \multicolumn{6}{|c|}{ TYRIMAI } \\
\hline & I & II & III & IV & $\mathrm{V}$ & $\begin{array}{c}\text { I ir V tyrimų } \\
\text { skirtumo } \\
\text { patikimumas }\end{array}$ \\
\hline $\begin{array}{l}\text { Funkcinis } \\
\text { pastovumas }\end{array}$ & $68,89 \pm 1,58$ & $71,04 \pm 2,22$ & $71,56 \pm 3,60$ & $72,07 \pm 3,92$ & $75,20 \pm 2,99$ & $\mathrm{p}<0,05$ \\
\hline Paslankumas & $76,83 \pm 2,70$ & $82,40 \pm 2,58$ & $80,20 \pm 2,70$ & $80,57 \pm 4,17$ & $83,32 \pm 1,97$ & $\mathrm{p}<0,05$ \\
\hline $\begin{array}{l}\text { Bendrasis } \\
\text { darbingumas }\end{array}$ & $56,30 \pm 1,56$ & $57,97 \pm 1,35$ & $58,75 \pm 1,17$ & $59,83 \pm 1,53$ & $58,42 \pm 1,67$ & $\mathrm{p}>0,05$ \\
\hline $\begin{array}{l}\text { Anaerobinis } \\
\text { darbingumas }\end{array}$ & $67,41 \pm 1,91$ & $69,81 \pm 1,59$ & $68,34 \pm 1,34$ & $71,86 \pm 2,47$ & $68,16 \pm 2,11$ & $\mathrm{p}>0,05$ \\
\hline $\begin{array}{l}\text { Anaerobiné } \\
\text { talpa }\end{array}$ & $58,31 \pm 1,67$ & $59,29 \pm 1,25$ & $60,63 \pm 1,20$ & $61,86 \pm 1,61$ & $59,86 \pm 1,67$ & $\mathrm{p}>0,05$ \\
\hline
\end{tabular}

1 lentelè. CNS darbingumo ir funkcinès būklès rodiklių kaita (\%) rudens ir žiemos sezono rengimo etapais 


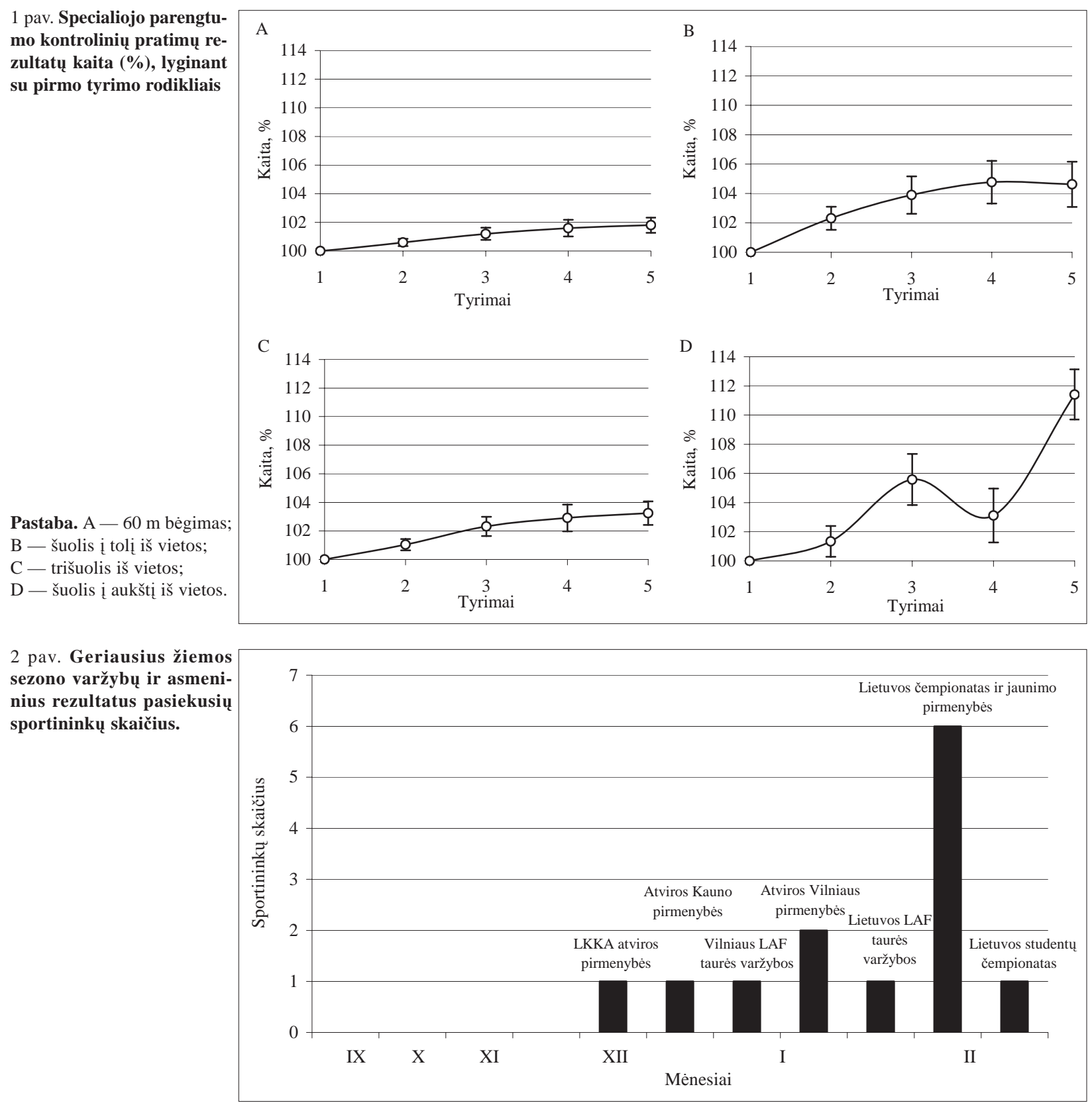

dines žiemos sezono varžybas, ir šis skirtumas nebuvo statistiškai reikšmingas $(\mathrm{p}>0,05)$.

1 paveiksle pateikta tirtų lengvaatlečiu specialiojo parengtumo kontrolinių pratimų rezultatų kaita. Nustatyta, kad treniruotès vyksme taikomi kontroliniai pratimai parodo atletu parengtumo kaitą. Visais pasirengimo etapais rezultatai gerejjo, o puikiausių rodiklių buvo pasiekta prieš atsakingiausias žiemos sezono varžybas, t. y. Lietuvos lengvosios atletikos žiemos čempionatą. Lyginant šių kontrolinių pratimų rezultatų procentini prieaugi su rezultatais, gautais pirmo tyrimo metu, aptiktas statistiškai reikšmingas skirtumas $(\mathrm{p}<0,05)$.

Lyginant pirmą tyrimą su penktu (prieš pat atsakingiausias varžybas), didžiausias procentinis rezultatų prieaugis užregistruotas atliekant šuoli i aukštị iš vietos, ir tai sudarè $11,41 \%$. Kiek mažiau reikšmingas buvo šuolio ị toli iš vietos rezultatų pagerèjimas - 4,6\%. Dar mažiau reikšmingas prieaugis užregistruotas trišuolio iš vietos ir $60 \mathrm{~m}$ bėgimo - atitinkamai 3,20 ir 2,70\%. Tai atitiko rezultatus, pasiektus per paskutini pasirengimo mikrociklą, t. y. prieš pagrindines žiemos sezono varžybas - Lietuvos lengvosios atletikos žiemos čempionatą.

2 paveiksle parodytas skaičius tirtų lengvaatlečių, žiemos sezono varžybose pasiekusių geriausius ir net savo asmeninius rezultatus. Tik du tiriamieji jau pirmose dvejose varžybose, kurios buvo kontrolinès, pasiekè savo geriausius sezono rezultatus ir vèliau jų nepagerino. 
Du geriausi žiemos sezono rezultatai buvo pasiekti sausio mėnesí, likus trims savaitėms iki Lietuvos suaugusiujų čempionato, t. y. svarbiausių žiemos sezono varžybų. Visgi daugiausia asmeninių ir geriausių sezono varžybų rezultatų buvo pasiekta būtent per pagrindines žiemos sezono varžybas, t. y. Lietuvos suaugusiujų čempionate ir jaunimo pirmenybėse, kurios vyko $2005 \mathrm{~m}$. vasario $11-12$ d. Net keturi sportininkai pasiekè savo asmeninius rekordus, o du — geriausią šiu žiemos sezono varžybų rezultatą.

\section{REZULTATŲ APTARIMAS}

Yra skiriami labai reikšmingi sporto treniruotès tikslai: 1) gauti ilgalaikès adaptacijos efekta; 2) igyti sportinę formą reikiamu momentu. Aukščiausias treniruotumo lygis, pasiektas tam tikru pasirengimo laikotarpiu, pageidautina varžybiniu, ir būtent atsakingiausių sezono varžybų metu, yra vadinamas gera sportine forma. Tai, kitaip tariant, yra kumuliacinio treniruotès efekto gavimas (Poderys, 2004; Платонов, 2004), t. y. kai yra pasiektas visu sportininko organų bei sistemų didelis funkcinis pajègumas, didžiausias darbingumas ir tobula jų veiklos koordinacija. Sportinè forma igyjama pamažu didinant pratybų krūvị, kryptingai taikant fizinius krūvius parengiamuoju ir priešvaržybiniais treniruotès etapais (Skernevičius, 1997; Karoblis, 1999; Платонов, 2004).

Tyrimo rezultatai parodè, kad lengvosios atletikos treneriai tinkamai suplanavo ir vykde treniruotės vyksmo programa, ir tirti sportininkai atsakingiausiose žiemos sezono varžybose pasiekė daugiau asmeninių arba geriausių sezono rezultatu.

Sportininkų treniruotumo gerejjimą rodè ir laboratorinių tyrimų duomenys. Rengiantis žiemos sezono varžyboms, CNS funkcinès būklès rodikliai gerèjo, tačiau prieš atsakingiausias sezono varžybas smarkiai pagerejjo CNS funkcinio paslankumo ir funkcinio pastovumo rodikliai, o anaerobinio darbingumo ir anaerobinio darbingumo talpos rodikliai reikšmingai sumažèjo, ir tai gali būti susiję su psichologiniu priešvaržybiniu stresu. Priešvaržybinio streso poveiki iprastoms organizmo reakcijoms nurodo V. Issurin (Issurin et al., 2005). Jis teigia, kad jeigu dèl treniruočiu sumažèja testosterono ir padidejja kortizolio sekrecija organizme, tai priešvaržybiniu laikotarpiu sumažinus krūvius turètų atsirasti priešingi pokyčiai. Kaip teigia prof. V. Issurin, priešvaržybinis stresas (jis būdingas tik prieš atsakingiausias varžybas), pakeičia hormonines reakcijas, ir dèl to testosterono sekrecija sumažèja, o kortizolio - padaugejja. Taip pat mažèja ir sportininko organizmo anaerobinis darbingumas, ima vyrauti kataboliniai procesai. Taigi manome, kad šis fenomenas iš dalies turejjo įtakos. Tirtiems sportininkams Lietuvos žiemos čempionato varžybos buvo pačios svarbiausios. Taigi nors iš esmès CNS funkcinès būklès ir darbingumo rodikliai gerejjo, tačiau anaerobinio darbingumo ir anaerobinès talpos rodiklių pablogejjimas, matyt, gali būti susijęs su priešvaržybiniu stresu (Issurin, 2005).

Vertindami tyrimo rezultatus turime pažymèti, kad lengvaatlečių parengtumui kontroliuoti parinkome iprastinius rekomenduojamus kontrolinius pratimus: $60 \mathrm{~m}$ bėgima, šuolị i tolị ir trišuolị iš vietos, šuoli i aukštị iš vietos. Iš tyrimo rezultatu matyti, kad greitumo jejgos rungčių lengvaatlečių treniruotès vyksme taikomi kontroliniai pratimai gerai parodo jų parengtumo kaitą. Pasirengimo etapais rezultatai gerejo, o puikiausių rodikliu buvo pasiekta, kaip ir turètų būti tinkamai suplanavus treniruotès vyksma, prieš atsakingiausias sezono varžybas (Skernevičius, 1997; Karoblis, 1999; Платонов, 2004). Gauti rezultatai patvirtino, kad lengvosios atletikos treneriai tinkamai suplanavo ir vykdè tirtų sportininkų treniruotès vyksmą. Sportininkų varžybinès veiklos rezultatų kaita liudijo, kad rudens ir žiemos parengiamuoju laikotarpiu taikyti krūvio dydžiai, jų intensyvumas ir kaita, pereinant iš vieno treniruotės etapo i kita, buvo suplanuoti tinkamai. Vertindami sportinès formos pokyčius galime konstatuoti, kad prieš pagrindines žiemos sezono varžybas tirti sportininkai buvo igiję optimalią sportinę formą.

Apibendrinant šio tyrimo rezultatus, galima konstatuoti, kad per treniruotės vyksmą ne visi CNS darbingumo bei funkcinès būkles rodikliai kinta vienareikšmiškai ir tolygiai. Prieš atsakingiausias varžybas CNS funkciniai rodikliai kinta skirtingai, t. y. kai vieni iš ju smarkiai gerejja, kiti, priešingai — reikšmingai blogèja.

\section{IŠVADOS}

1. Greitumo jègos rungčių lengvaatlečių treniruotès vyksme taikomi kontroliniai pratimai gerai parodo jų parengtumo kaitą. Atskirais pasirengimo etapais kontrolinių pratimų rezultatai ge- 
rèjo, o puikiausių rodiklių buvo pasiekta prieš atsakingiausias sezono varžybas.

2. Rengiantis žiemos sezono varžyboms, CNS funkcinès būklès rodikliai gerèjo, tačiau prieš atsakingiausias sezono varžybas smarkiai išaugus CNS funkcinio paslankumo ir funkcinio pastovumo rodikliams anaerobinio darbingu- mo ir anaerobinio darbingumo talpos rodikliai reikšmingai sumažèjo, ir tai gali būti susiję su psichologiniu priešvaržybiniu stresu.

3. Sportininkų parengtumo ir funkcinès būklès kaitą geriausiai rodo kontroliniai pratimai ir CNS funkciniai rodikliai - funkcinis paslankumas ir funkcinis pastovumas.

\title{
LITERATŪRA
}

Bangsbo, J. (1998). Quantification of anaerobic energy production during intense exercise. Medicine and Science in Sports and Exercise, 30, 47-52.

Bosco, C. (1999). Strength assessment with the Bosco's test. Roma: Italian Society of Sport Science.

Edgerton, V. R., Roy, R. R., Gregor, R. J., Rugg, S. (1986). Morphological basis of skeletal muscle power output. Human Kinetics.

Issurin, V., Kaufman, L., Lustig, G. (2005). Peaking: revised approach following evidence from the Athens Olimpic games. Scientific Management of High Performance Athletes' Training: 8th International Sports Science Conference: Book of Abstracts (p. 16). Vilnius.

Jasiūnas, V. (1982). Sporto treniruočiu krūvio parametru ir testavimo rezultatu kontrole ir jevertinimas. Vilnius. P. 4.

Karoblis, P. (1994). Sportinès treniruotès struktūra ir valdymas. Vilnius. P. 13, 25.

Karoblis, P. (1999). Sportinès treniruotès teorija ir didaktika. Vilnius. P. 33, 50-56, 315-316.

Maud, P. J., Foster, C. (1995). Physiological assessment of Human Fitness. Champaign: Human Kinetics. P. 296.
Poderys, J. (2004). Judesių fiziologiniai ir biocheminiai pagrindai. Kineziologijos pagrindai, 146-155.

Poderys, J., Poderytė, K., Snarskaitè, R. (2002). Didelio meistriškumo sportininku parengtumo ir organizmo funkcinès būklès vertinimas pagal raumenų anaerobinio darbingumo bei širdies ir kraujagyslių sistemos funkcinès būklès rodiklius. Sporto mokslas, 1, 45-48.

Raslanas, A., Skernevičius, J. (1998). Sportininku testavimas. P. 18-17, 81, 128.

Skernevičius, J. (1997). Sporto treniruotès psichologija. Vilnius. P. 72-74.

Šiupšinskas, L. (2004). Fizinio aktyvumo ir sveikatos vertinimai. Kineziologijos pagrindai, 177-188.

Зеленцов, А. М., Лобановский, В.В.(1998). Моделирование тренировки в футболе. Киев. С. 214.

Платонов, В. Н. (1997). Общая теория подготовки спортсменов в олимпийском спорте: учебник для студентов вузов физического воспитания и спорта. Киев: Олимпийская литература. С. 554-566.

Платонов, В. Н. (2004). Система подготовки спортсменов в олимпийском спорте. В кн.: Общзая теоря и её практические приложения. Киев: Олимпийская литература. С. 808.

\section{CONTROL AND MANAGEMENT OF TRAINING PROCESS OF HIGH SKILLED ATHLETES}

\author{
Eugenijus Trinkūnas, Jonas Poderys, Jūratė Kudirkaitė, Eurelija Venskaitytė \\ Lithuanian Academy of Physical Education, Kaunas, Lithuania
}

\begin{abstract}
Information about individual peculiarities of athletes and their changes under training are the main reason for successful management of training process. Usually this information can be obtained from special tests, control exercises, functional and biochemical researches. Unsuccessful competition usually is the reason of inability to be in a good or best functional state on time. It is important to determine the purpose of educational and practical training, change the training load, to control functional abilities and recovery processes as well. The aim of this study was to manage the training process of highly skilled athletes during their preparation for the winter season by using the functional indices of central nervous system (CNS) and
\end{abstract}


testing results by using the special control exercises. The subjects in this study were 12 athletes - sprint runners and long jumpers. All participants of this study after each of training mesocycle performed special control exercises and at the same day participated in the evaluation of functional indices of CNS. The modified Tapping-test in accordance with scientists of Ukrainian Physical Education University was used. The test allowed to establish the following indices: CNS mobility, CNS functional stability, total working capacity, anaerobic power and aerobic capacity. We used a common and recommended control exercises for athletes, i. e. $40 \mathrm{~m}$ running, broad long jump, triple jump and vertical jump. We have made the analysis of sport results in winter season.

The results obtained during this study showed that CNS functional indices marked increase of athlete's preparation for winter season competitions and before the main winter season competitions significantly increased the indices of CNS: functional mobility and functional stability, and the indices of anaerobic power and anaerobic capacity decreased significantly. This may be related to psychological stress before the competitions. Our results propose the same idea as it was established by V. Issurin (2005), that stress before the competitions (usually before the main competitions) modifies, changes the body functioning, i. e. hormone reactions so that testosterone decreases and cortisol increases. Therefore in these condition anaerobic abilities decrease and catabolic processes are prevailing. The results of evaluation of special preparation of athletes using the control exercises have showed that these results correspondent to all changes of functional preparedness and abilities of athletes to reach appropriate sport results. The results have increased in all preparation stages and the highest values were reached before the main winter season competitions - National Athletics Championship. The analysis of competitions results showed that even six sportsmen (50 percent) have reached the best winter season or their personal best results during the main competitions. In conclusion, we can point out that the participant of this study reached the top performance abilities exactly before the main competition as it has been planed.

Keywords: functional state, special preparation, top performance abilities.

Gauta 2006 m. vasario 13 d.

Received on February 13, 2006

Priimta 2006 m. gegužès 25 d.

Accepted on May 25, 2006

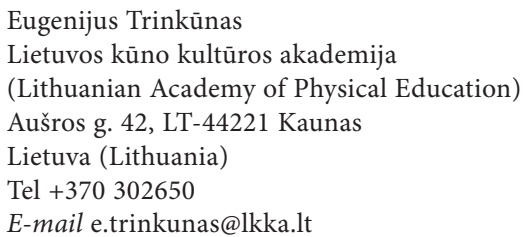

